\title{
Impact of Knowledge Management on Teachers' Functional Performance in Secondary Schools in Rivers State, Nigeria
}

\author{
Dr. Ohia Adanma Ngozi \\ Department of Educational Management \\ Faculty of Education \\ University of Port Harcourt \\ PMB 5323, Choba \\ Rivers State, Nigeria
}

\begin{abstract}
The study examined the impact of knowledge management by way of knowledge creation and knowledge transfer on the functional performance of teachers in public secondary schools in Rivers State. Three research questions and three hypotheses guided the study. The sample was 1,210 (14.8\%) teachers from 100 (40.5\%) public secondary schools got using stratified random sampling technique. Data were collected using a researcherstructured instrument titled "Knowledge Management and Teachers' Functional Performance Scale, (KMTFPS)". The instrument was validated and has a reliability index of 0.75 got using test-retest method and calculated using Pearson's Product Moment Correlation. The findings include that knowledge transfer can enhance teachers' functional performance through, for instance, assisting teachers in proper planning of classroom instructions. The study concluded that encouraging team performance and knowledge sharing will engender the teachers' functional performance.
\end{abstract}

Keywords: knowledge management, functional performance, secondary school teachers

\subsection{Introduction}

There is need for educational institutions to understand and appreciate knowledge as the most valued asset in the emerging competitive environment. Educational institutions have the potentials to learn and integrate new knowledge into specific practices, so that, the knowledge becomes accessible to staff, students and other researchers. Knowledge management is the explicit and systematic management of vital knowledge and its associated processes of creating, gathering, organizing, diffusion, use and exploitation within the education system (Madumere-Obike \& Nwabueze, 2012). Knowledge management is the process through which organizations generate value from their intellectuals and knowledge-based assets for staff productivity.

Management of knowledge in organizations entails relying on the concepts and constructs that are theoretically sound, which cover the most important areas of knowledge processes; these knowledge processes are easy to communicate and integrate in the practical action within the organization. According to Marwick (2001), efficient and effective knowledge management typically requires an appropriate combination of organisational, social, and managerial initiatives along with the deployment of appropriate technology.

Awad and Ghaziri (2007) define knowledge as the understanding that is obtained through the process of experience or appropriate study. Knowledge management is concerned with the exploitation and development of the knowledge assets of an institution with a view to further the aim and objectives of such institution. Knowledge management in education is a monograph that makes eminent sense; a wonderful combination of good intuition, practical know-how, and a feel for what might be best described as a set of emerging theories focusing on the effective management of knowledge in educational institutions (Nwabueze, 2011); explaining further that, knowledge management in education supplies us with a framework for understanding how good assessment practice depends on effective information generation and transfer. However, knowledge creation, sharing and transfer could be seen as the processes of managing knowledge in an educational institution. Knowledge creation is the ability to research and acquire new knowledge and skills that are transferrable to others. It encourages knowledge exchange or transfer to other members of the organization, as well as develops competitive advantages, such as intellectual capital and innovative ideas. 
In addition, since knowledge is a key in achieving continuous innovation, innovation and knowledge are closely related. Therefore, knowledge management has become an important activity for the educational industry; as its management covers a wide range of topics. In addition, the knowledge life cycle, knowledge capture, knowledge development, knowledge sharing, and knowledge utilization all have become strategic necessities for organization to integrate with their Information Technology capabilities (Lee \& Hong, 2002).

Knowledge management may include a relationship between knowledge sharing, absorptive capacity and innovation capability. An interesting characteristic of knowledge is the fact that its value grows when it is shared. As one shares knowledge acquired with others, not only do those units gain information (linear growth), they equally share it with others with feedback questions, amplifications, and modifications that add further value for the original sender, creating exponential total growth. Knowledge sharing among teachers is a major issue in current movements of education reform and school improvement. As a matter of fact, Ohia \& Obasi (2015) posit that academic and professional standards of teachers are strategic in any education reform geared towards achieving national educational goals. By sharing their knowledge, teachers gain more than they lose. Sharing knowledge is a synergistic process needed by teachers in the school system for productivity. When teachers share an idea with one another, the act of putting their ideas into words or writing will help them shape and improve their instructions.

The purpose of education is to share knowledge with others, and great teachers can impart deep understanding of a subject to staff or students effectively; however, with passion and hope, those young people will be inspired to teach others. Knowledge sharing is the fundamental means through which employees can contribute to knowledge application, innovation, and ultimately be in the competitive advantage of educational institutions (MadumereObike, Ukala \& Nwabueze, 2015). Knowledge sharing between employees within and across teams allows organizations to exploit and capitalize on knowledge-based resources. Hence, knowledge sharing and combination are positively related to reductions in production costs, faster completion of new product development projects, team performance, firm innovation capabilities, and firm performance including sales growth and revenue from new products and services (Madumere-Obike \& Nwabueze, 2012; Arthur \& Huntley, 2005; Hansen, 2002).

Knowledge transfer is the practical process of transferring knowledge from a teacher to the learner. Like knowledge management, knowledge transfer seeks to organize, create, capture or distribute knowledge and ensure its availability for future users. It is considered to be more than just a communication process. Argote and Ingram (2000) define knowledge transfer as the process through which one unit (e.g., group, department, or division) is affected by the experience of another. They further point out the transfer of organizational knowledge (i.e., routine or best practices), which can be observed through changes in the knowledge or performance of recipient units. The transfer of organizational knowledge, such as best practices can be quite difficult to achieve.

Knowledge transfer is a major concern in improving educational practices (Huberman, 2002; Love, 2005). Actually, despite the fact that new information and communication technologies have made it much easier for practitioners to access research results, there is still a large gap between the knowledge produced by research providers and the one used in practice.

\subsection{Statement of the Problem}

Education industry operates in environments characterized by increased need for knowledge to create and sustain competitive differentiation. In order for institutions to succeed in highly dynamic business environment, it is critical that they embrace and institutionalize Knowledge management in their academic activities. Institutions therefore, need to be cognizant of the factors that influence the success of institutionalization of Knowledge Management initiatives. Furthermore, knowledge management is taking centre stage in educational management especially with the emergence of the knowledge economy.

In secondary schools in Rivers State, teachers seem not to have the leadership skills needed for academic growth and students' productivity. Male and female teachers seem to lack the knowledge of operating the new technological devices needed to transform knowledge for teachers' productivity. Teachers in urban and rural located schools seem not to participate equally in professional development programmes for knowledge building. They also, seem not to engage themselves in mentoring programmes, which affects their improvement negatively in knowledge building and development. 


\subsection{Purpose of the Study}

The study investigated the perceived impact of knowledge management on teachers' functional performance in secondary schools in Rivers State. Specifically, the objectives are to:

1.ascertain the ways knowledge creation exercises enhance teachers' functional performance in secondary schools;

2. ascertain ways knowledge sharing among teachers can enhance teachers' functional performance in secondary schools;

3.ascertain the ways knowledge transfer exercises enhance teachers' functional performance in secondary schools.

\subsection{Research Questions}

The following research questions guided this study:

1.How can knowledge creation exercises enhance teachers' functional performance in secondary schools?

2.How can knowledge sharing among teachers enhance teachers' functional performance in secondary schools?

3.In what ways do knowledge transfer exercises enhance teachers' functional performance in secondary schools?

\subsection{Hypotheses}

There is no significant difference between the mean ratings of male and female teachers on the ways knowledge creation exercises enhance teachers' functional performance in secondary schools.

1. There is no significant difference between the mean ratings of teachers in rural and urban schools on the ways knowledge sharing among teachers enhances teachers' productivity in secondary schools.

2. There is no significant difference between the mean ratings of male and female teachers on the ways knowledge transfer exercises enhance teachers' functional performance in secondary schools.

\subsection{Methodology}

The design for this study was descriptive survey. The population of consisted of all the 247 public senior secondary schools in Rivers State with 8,205 teaching staff. There are 4,313 male teaching staff and 3,892 female teaching staff; while the rural areas and urban areas of the state have 5,240 and 2,965 teaching staff respectively. A sample size of 1,210 teaching staff was drawn using stratified random sampling technique representing $14.8 \%$ of the entire population of the study. This was drawn from 100 secondary schools involving 60 schools from rural areas and 40 schools from urban areas. Based on this, 800 teaching staff were randomly drawn from secondary schools in rural areas while 410 teaching staff from urban areas; also, 700 male teaching staff and 510 female teaching staff. The instrument used for data collection was scale titled "Knowledge Management and Teachers' Functional Performance Scale (KMTPS)" developed by the researcher. The instrument was validated and the reliability carried out with test-retest method and calculated using Pearson's Product Moment Correlation, which yielded an index of 0.65. During administration of instrument, there was 99.2\% retrieval as only 1,200 copies of questionnaire were completely filled, returned and used for data analysis (800 staff from rural areas; 400 staff from urban areas; 700 male teaching staff; and 500 female teaching staff). Mean scores and standard deviation were used to answer the research questions. The null hypotheses were tested with z-test at 0.05 level of significance.

\subsection{Results}

Research Question One: How can knowledge creation exercises enhance teachers' functional performance in secondary schools in Rivers State? 
Table 1: Mean scores and standard deviations of respondents on the ways knowledge creation exercises can enhance teachers' functional performance

\begin{tabular}{|c|c|c|c|c|c|c|c|}
\hline \multirow[t]{2}{*}{$\mathrm{S} / \mathrm{N}$} & \multirow[t]{2}{*}{ Knowledge creation exercises } & \multicolumn{2}{|c|}{ Male (700) } & \multicolumn{2}{|c|}{ Female (500) } & \multirow{2}{*}{$\begin{array}{l}\text { Mean } \\
\text { Set }\end{array}$} & \multirow[t]{2}{*}{ Decision } \\
\hline & & Mean & SD & Mean & SD & & \\
\hline & $\begin{array}{l}\text { knowledge creation exercise helps the teachers to } \\
\text { be active in improvising instructional materials } \\
\text { needed for teaching }\end{array}$ & 3.02 & 0.26 & 3.08 & 0.31 & 3.05 & Agreed \\
\hline & $\begin{array}{l}\text { It motivates them to carry out their duties more } \\
\text { effectively }\end{array}$ & 2.87 & 0.27 & 2.79 & 0.32 & 2.83 & Agreed \\
\hline & $\begin{array}{l}\text { It encourages them to acquire the knowledge of ICT } \\
\text { applications }\end{array}$ & 3.21 & 0.26 & 3.15 & 0.31 & 3.18 & Agreed \\
\hline & $\begin{array}{l}\text { Enables them in the management of time for } \\
\text { instructional purpose }\end{array}$ & 3.12 & 0.26 & 3.16 & 0.31 & 3.14 & Agreed \\
\hline & Helps them to be active in research publications & 3.32 & 0.25 & 3.26 & 0.30 & 3.29 & Agreed \\
\hline & Enhances staff conditions of service & 2.82 & 0.27 & 2.88 & 0.32 & 2.85 & Agreed \\
\hline & Promotes team-building among staff & 3.09 & 0.26 & 3.17 & 0.31 & 3.13 & Agreed \\
\hline & $\begin{array}{l}\text { Energizes them to participate in professional } \\
\text { development programmes }\end{array}$ & 3.25 & 0.26 & 3.13 & 0.31 & 3.19 & Agreed \\
\hline & Aggregate Mean Scores & 3.09 & 0.26 & 3.08 & 0.31 & 3.09 & Agreed \\
\hline
\end{tabular}

Data in Table 1 showed the mean scores and standard deviations of teaching staff on the ways knowledge creation exercises can enhance teachers' functional performance in secondary schools. The respondents agreed on all the items in the table with mean scores above the mean criterion of 2.50. The aggregate mean scores of 3.09 and 3.08 for male and female teachers respectively indicated that, the items in the table are ways of creating knowledge to enhance teachers' functional performance; which includes: helping the teachers to be active in improvising instructional materials needed for teaching, motivating them to carry out their duties more effectively, encouraging them to acquire the knowledge of ICT applications, enabling them in the management of time for instructional purpose, helping them to be active in research publications, enhancing their conditions of service, promoting team-building among staff, and energizing them to participate in professional development programmes.

Research Question Two: How can knowledge sharing among teachers enhance teachers' functional performance in secondary schools in Rivers State?

Table 2: Mean scores and standard deviations of respondents on the ways knowledge sharing among teachers can enhance teachers' functional performance

\begin{tabular}{|c|c|c|c|c|c|c|c|}
\hline \multirow[t]{2}{*}{$\mathrm{S} / \mathrm{N}$} & \multirow[t]{2}{*}{ Knowledge Sharing exercises } & \multicolumn{2}{|c|}{ Rural (800) } & \multicolumn{2}{|c|}{ Urban (400) } & \multirow{2}{*}{$\begin{array}{l}\text { Mean } \\
\text { Set }\end{array}$} & \multirow[t]{2}{*}{$\overline{\text { Decision }}$} \\
\hline & & Mean & SD & Mean & SD & & \\
\hline & $\begin{array}{l}\text { Knowledge sharing allows educational institutions } \\
\text { to exploit on knowledge-based resources }\end{array}$ & 3.14 & 0.24 & 3.10 & 0.35 & 3.12 & Agreed \\
\hline & It helps in reducing educational costs & 3.27 & 0.24 & 3.19 & 0.34 & 3.23 & Agreed \\
\hline & $\begin{array}{l}\text { It enhances faster completion of knowledge } \\
\text { programmes in the school system }\end{array}$ & 3.31 & 0.23 & 3.25 & 0.34 & 3.28 & Agreed \\
\hline & It encourages team performance among staff & 3.22 & 0.24 & 3.36 & 0.33 & 3.29 & Agreed \\
\hline & It promotes innovation capabilities among staff & 3.17 & 0.24 & 3.11 & 0.35 & 3.14 & Agreed \\
\hline & $\begin{array}{l}\text { It encourages educational growth with the } \\
\text { development of teachers }\end{array}$ & 3.08 & 0.25 & 3.02 & 0.35 & 3.05 & Agreed \\
\hline & It enhances knowledge capture among staff & 3.15 & 0.24 & 3.21 & 0.34 & 3.18 & Agreed \\
\hline & Aggregate Mean Scores & 3.19 & 0.24 & 3.18 & 0.34 & 3.19 & Agreed \\
\hline
\end{tabular}

Data in Table 2 showed the mean scores and standard deviations of teaching staff on the ways knowledge sharing among teachers can enhance teachers' functional performance in secondary schools in Rivers State. The respondents agreed on all the items in the table with mean scores above the mean criterion of 2.50. The aggregate mean scores of 3.19 and 3.18 for teachers in rural and urban areas respectively indicated that the items in the table are ways of sharing knowledge among teaching staff to enhance their functional performance. 
They include: allowing educational institutions to exploit on knowledge-based resources, helping in reducing educational costs, enhancing faster completion of knowledge programmes in the school system, encouraging team performance among staff, promoting innovation capabilities among staff, encouraging educational growth with the development of teachers, and enhancing knowledge capture among staff.

Research Question Three: In what ways can knowledge transfer exercises enhance teachers' functional performance in secondary schools in Rivers State?

Table 3: Mean scores and standard deviations of respondents on the ways knowledge transfer exercises can enhance teachers' functional performance

\begin{tabular}{|c|c|c|c|c|c|c|c|}
\hline \multirow[t]{2}{*}{$\mathrm{S} / \mathrm{N}$} & \multirow[t]{2}{*}{ Knowledge Transfer exercises } & \multicolumn{2}{|c|}{ Male (700) } & \multicolumn{2}{|c|}{ Female (500) } & \multirow{2}{*}{$\begin{array}{l}\text { Mean } \\
\text { Set }\end{array}$} & \multirow[t]{2}{*}{ Decision } \\
\hline & & Mean & SD & Mean & SD & & \\
\hline ' & $\begin{array}{l}\text { Knowledge transfer exercise assists teachers in } \\
\text { proper planning of classroom instruction }\end{array}$ & 3.23 & 0.26 & 3.29 & 0.30 & 3.26 & Agreed \\
\hline . & $\begin{array}{l}\text { Equips them with the right skills to transfer } \\
\text { knowledge into students }\end{array}$ & 3.34 & 0.25 & 3.42 & 0.29 & 3.38 & Agreed \\
\hline ' & $\begin{array}{l}\text { Helps them acquire series of ideas to promote } \\
\text { learning }\end{array}$ & 3.21 & 0.26 & 3.15 & 0.31 & 3.18 & Agreed \\
\hline . & $\begin{array}{l}\text { Helps them to become creative in their subject } \\
\text { areas }\end{array}$ & 3.25 & 0.26 & 3.35 & 0.30 & 3.30 & Agreed \\
\hline . & $\begin{array}{l}\text { Helps them manage their academic time } \\
\text { appropriately }\end{array}$ & 3.33 & 0.25 & 3.39 & 0.29 & 3.36 & Agreed \\
\hline . & $\begin{array}{l}\text { Promotes innovative ideas of handling students in } \\
\text { classroom interactions }\end{array}$ & 3.17 & 0.26 & 3.21 & 0.31 & 3.19 & Agreed \\
\hline ' & Transfers new knowledge through teaching & 3.31 & 0.25 & 3.27 & 0.30 & 3.29 & Agreed \\
\hline . & $\begin{array}{l}\text { Transfers new knowledge through regular } \\
\text { involvement of staff in workshops }\end{array}$ & 3.35 & 0.25 & 3.45 & 0.29 & 3.40 & Agreed \\
\hline . & $\begin{array}{l}\text { Cross-fertilizing positive ideas through active } \\
\text { involvement in seminars }\end{array}$ & 3.29 & 0.25 & 3.37 & 0.29 & 3.33 & \\
\hline & Aggregate Mean Scores & 3.28 & 0.25 & 3.32 & 0.30 & 3.30 & Agreed \\
\hline
\end{tabular}

Data in Table 3 showed the mean scores and standard deviations of teaching staff on the ways knowledge transfer exercises can enhance teachers' functional performance in secondary schools in Rivers State. The respondents agreed on all the items in the table with mean scores above the mean criterion of 2.50 . The aggregate mean scores of 3.28 and 3.32 for male and female teachers respectively indicated that, the items in the table are ways of transferring knowledge to enhance teachers' functional performance. They include: assisting teachers in proper planning of classroom instruction, equipping them with the right skills to transfer knowledge into students, helping them acquire series of ideas to promote learning, helping them to become creative in their subject areas, helping them manage their academic time appropriately, promoting innovative ideas of handling students in classroom interactions, transferring new knowledge through teaching, transferring new knowledge through regular involvement of staff in workshops, and cross-fertilizing positive ideas through active involvement in seminars.

\subsection{Test of Hypotheses}

Hypothesis One: There is no significant difference between the mean ratings of male and female teachers on the ways knowledge creation exercises enhance teachers' functional performance in secondary schools in Rivers State.

Table 4: Summary of z-test analysis on the difference between mean scores of male and female teachers on the ways knowledge creation exercises enhance teachers' functional performance

\begin{tabular}{|c|c|c|c|c|c|c|c|}
\hline Gender of Staff & $\mathrm{N}$ & Mean & St. Dev. & $\mathrm{df}$ & $\begin{array}{l}\text { Z-calculated } \\
\text { value }\end{array}$ & $\begin{array}{l}\text { Z-critical } \\
\text { value }\end{array}$ & Decision \\
\hline Male & 700 & 3.09 & 0.26 & 1198 & 0.967 & \pm 1.961 & Not \\
\hline Female & 500 & 3.08 & 0.31 & & & & Significant \\
\hline
\end{tabular}


Data in table 4 presented the summary of z-test analysis on the difference between mean scores of male and female teachers on the ways knowledge creation exercises enhance teachers' functional performance, which showed that the z-calculated value of 0.967 is less than the z-critical value of \pm 1.961 at 0.05 level of significance and 1198 degree of freedom. Base on this, the null hypothesis was not rejected. Therefore, there is no significant difference between the mean score ratings of male and female teachers on the ways knowledge creation exercises enhance teachers' functional performance.

Hypothesis Two: There is no significant difference between the mean ratings of teachers in rural and urban areas on the ways knowledge sharing among teachers enhances teachers' functional performance in secondary schools in Rivers State.

Table 5: summary of z-test analysis on the difference between the mean ratings of teachers in rural and urban areas on the ways knowledge sharing among teachers enhances teachers' functional performance

\begin{tabular}{llllllll}
\hline Location of Staff & $\mathrm{N}$ & Mean & S.D & df & $\begin{array}{l}\text { Z-calculated } \\
\text { value }\end{array}$ & $\begin{array}{l}\text { Z-critical } \\
\text { value } \\
\pm 1.961\end{array}$ & Decision \\
Rural & 800 & 3.19 & 0.24 & 1198 & 1.216 & & $\begin{array}{l}\text { Not } \\
\text { Significant }\end{array}$ \\
\hline
\end{tabular}

Data in Table 5 presented the summary of z-test analysis on the difference between the mean ratings of teachers in rural and urban areas on the ways knowledge sharing among teachers enhances teachers' functional performance, which showed that the z-calculated value of 1.216 is less than the z-critical value of \pm 1.961 at 0.05 level of significance and 1198 degree of freedom. Based on this, the null hypothesis was not rejected. Therefore, there is no significant difference between the mean score ratings of teachers in rural and urban areas on the ways knowledge sharing among teachers enhances teachers' functional performance.

Hypothesis Three: There is no significant difference between the mean ratings of male and female teachers on the ways knowledge transfer exercises enhance teachers' functional performance in secondary schools in Rivers State.

Table 6: summary of z-test analysis on the difference between the mean ratings of male and female teachers on the ways knowledge transfer exercises enhance teachers' functional performance

\begin{tabular}{llllllll}
\hline Gender of Staff & $\mathrm{N}$ & Mean & St. Dev. & df & $\begin{array}{l}\text { Z-calculated } \\
\text { value }\end{array}$ & $\begin{array}{l}\text { Z-critical } \\
\text { value } \\
\pm 1.961\end{array}$ & $\begin{array}{l}\text { Decision } \\
\text { Male }\end{array}$ \\
Female & 700 & 3.28 & 0.25 & 1198 & -0.714 & & Significant \\
\hline
\end{tabular}

Data in Table 6 presented the summary of z-test analysis on the difference between the mean ratings of male and female teachers on the ways knowledge transfer exercises enhance teachers' functional performance, which showed that the z-calculated value of -0.714 is less than the $\mathrm{z}$-critical value of \pm 1.961 at 0.05 level of significance and 1198 degree of freedom. On this basis, the null hypothesis was not rejected. Therefore, there is no significant difference between the mean score ratings of male and female teachers on the ways knowledge transfer exercises enhance teachers' functional performance.

\subsection{Discussion of Findings}

The finding revealed that, the ways of creating knowledge to enhance teachers' functional performance include: helping the teachers to be active in improvising instructional materials needed for teaching, motivating them to carry out their duties more effectively, encouraging them to acquire the knowledge of ICT applications, enabling them in the management of time for instructional purpose, helping them to be active in research publications, enhancing their conditions of service, promoting team-building among staff, and energizing them to participate in professional development programmes. Proper involvement of teaching staff in the creation of knowledge through research and development would improve their functional performance in school activities. It would help them to master their subject areas properly. The test of hypothesis one showed that, there is no significant difference between the mean score ratings of male and female teachers on the ways knowledge creation exercises enhance teachers' functional performance. The staff all accepted that knowledge creation exercises improve teachers' functional performance in the school system. Knowledge creation encourages knowledge exchange and transfer to other members of the organization, as well as develops competitive advantages, such as intellectual capital and innovative ideas. 
In line with the finding, Lee and Hong (2002) were of the opinion that knowledge creation is key in achieving continuous innovations since innovation and knowledge are closely related. They include knowledge life cycle development, knowledge capture and knowledge utilization; and these have all become strategic necessities for organization to integrate with their information technology capabilities.

The finding also revealed that, the ways of sharing knowledge among teaching staff to enhances their functional performance include: allowing educational institutions to exploit on knowledge-based resources, helping in reducing educational costs, enhancing faster completion of knowledge programmes in the school system, encouraging team performance among staff, promoting innovation capabilities among staff, encouraging educational growth with the development of teachers, and enhancing knowledge capture among staff. Knowledge sharing among the teaching staff would help them to improve on the existing knowledge as well as build up new knowledge from divers groups. The test of hypothesis two showed that, there is no significant difference between the mean score ratings of teachers in rural and urban areas on the ways knowledge sharing among teachers enhances teachers' functional performance. The staff accepted that knowledge sharing among teachers promotes their functional performance. Knowledge sharing among teachers is a major issue in current movements of education reform as is corroborated by Ohia \& Obasi (2015) that the academic and professional teachers are important for any education reform. Sharing knowledge is a synergistic process needed by teachers in the school system for productivity. When teachers share an idea or a way of doing things with each other, then, just the act of putting their ideas into words or writing will help them shape and improve functional performances. Knowledge sharing between employees within and across teams allows organizations to exploit and capitalize on knowledge-based resources. In line with these findings, Madumere-Obike and Nwabueze, (2012) are of the view that knowledge sharing is positively related to reduction in production costs, faster completion of new product development projects, team performance, firm innovation capabilities, and firm performance including sales growth and revenue from new products and services.

The finding finally revealed that, the ways of transferring knowledge to enhance teachers' functional performance include: assisting teachers in proper planning of classroom instruction, equipping them with the right skills to transfer knowledge to students, helping them acquire series of ideas to promote learning, helping them to become creative in their subject areas, helping them manage their academic time appropriately, promoting innovative ideas of handling students in classroom interactions, transferring new knowledge through teaching, and regular involvement of staff in workshops, including cross-fertilizing positive ideas through active involvement in seminars. The transfer of knowledge from staff to staff and staff to students would properly help in knowledge building and production in the school system. Test of hypothesis three showed that, there is no significant difference between the mean score ratings of male and female teachers on the ways knowledge transfer exercises enhance teachers' functional performance. The staff all accepted that knowledge transfer exercises enhance teachers' functional performance. Knowledge transfer is the practical process of transferring knowledge from a teacher to the learner. It seeks to organize, create, capture or distribute knowledge and ensure its availability for future users.

\subsection{Conclusion}

This study had shown that proper knowledge management builds up adequate skill development and positive ideas in the teaching staff that knowledge creation will enhance their functional performance. Knowledge creation is essential but having the knowledge shared among the teaching staff is a good management strategy that helps in the cross-fertilization of positive ideas among groups for knowledge building and productivity. It encourages team performance among staff, innovative capabilities and educational growth with the development of teachers.

\subsection{Recommendations}

Based on the findings, the researcher made the following recommendations.

1. Teachers should be regularly involved in development programmes to be very active in improvising instructional materials needed for teaching and learning.

2. School administrators should regularly motivate teachers to be involved in ICT trainings to be acquainted with the applications and utilization of new technology devices for effective teaching and learning.

3. Teaching staff of secondary schools should endeavour to share and transfer new knowledge acquired among themselves to enhance their functional performance. 


\subsection{References}

Arthur, B. \& Huntley, O. (2005). Knowledge management and business intelligence strategies in Malaysian Universities. Universitiy Putra Malaysia Research Report.

Argote, L. \& Ingram, P. (2000). Knowledge Transfer in Organizations: Learning from the Experience of Others. Organizational Behavior and Human Decision Processes, 82(1), 18-25.

Awad, E. M., \& Ghaziri, H. M, (2007). Knowledge Management. New Delhi: Pearson Education

Hansen, J. I. (2002). The knowledge-creating school. British Journal of Educational Studies, 47(2): 122-144.

Huberman, M. A. (2002). Moving Towards the Inevitable: the sharing of research in education: Teachers and Teaching. Theory and Practice, 8(3): 257-268.

Lee, C.C., \& Hong, J. (2002). Knowledge value chain. Journal of management development. 19(9), 783-793.

Love, J. M. (2005). Knowledge transfer and utilization in education. Review of Research in Education, 12, 337386.

Madumere-Obike, C.U. \& Nwabueze, A.I. (2012). Practical application of knowledge management in university administration. Nigerian Journal of Educational Administration and Planning, 11(2); 127-147

Madumere-Obike, C.U., Ukala, C.C. \& Nwabueze, A.I. (2015). Developing knowledge management skills among male and female lecturers for capacity building in universities in South-East, Nigeria. International Publication of Education, Research and Innovation, Spain.

Marwick, A. D. (2001). Knowledge management technology. IBM Systems Journal, 40(4), 37-45.

Nwabueze, A.I. (2011). Benefits of knowledge management to educational administrators. Paper Presented at a Workshop on Improving Teacher Professional Competencies in the $21^{\text {st }}$ Century at BrainField Secondary School, Port Harcourt, Rivers State: $27^{\text {th }}-30^{\text {th }}$ August, 2011.

Ohia, A. N. \& Obasi, K. K. (2015). Repackaging teacher education in Nigeria for national development: the role of reflective teaching practice exercise. International Journal of Issues on African Development, 10(1), 217-237. 